
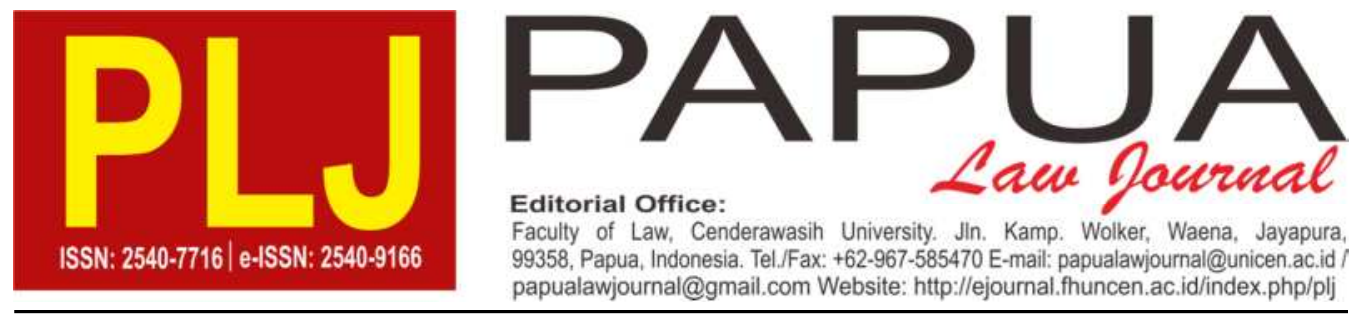

\title{
Responsibility of Local Government Against Sea Pollution, Plastic Waste In Sea Waters, Sorong City
}

\author{
Hotlan Samosir \\ Faculty of Law, Cenderawasih University \\ Jl. Kamp Wolker, Waena Jayapura, 99358 Papua Indonesia \\ Tel/Fax: +62-967-585470, Email : hotlan.samosir06@gmail.com
}

\begin{abstract}
This study aims to determine the impacts arising from the handling of waste (waste plastic) which is not effective in urban areas. Waste in urban areas that are not handled properly will be wasted into rivers and ends at sea. Increasing the amount of plastic waste in the marine waters of Sorong City can cause disruption to the convenience of sea users, especially for fishermen and tourists who aim to Raja Ampat regency. The wider impact due to increased waste of plastics in the marine waters of Sorong City is able to threaten the marine ecology.

Pollution of marine waters of Sorong City is the responsibility of local government that is local government of Sorong City. Efforts to overcome the pollution can be done by streamlining waste management in urban areas by socializing the use of government-provided waste containers provided by local government with color variations to distinguish types of organic waste and non-organic waste and wet garbage. Adjustment needs to be made between the number of residents with the availability of waste disposal facilities and including the janitor so that the waste can be handled up to the landfill (Final Disposal Place).
\end{abstract}

Keywords: Responsibility; Local Government; Sea Pollution.

\section{INTRODUCTION}

The foundation of thinking on the importance of maintaining a good and healthy environment is actually based on the nature of every human being lives in a clean and healthy environment. That is why awareness of a good environment and clean must be invested basically on every citizen because it is one of the basic needs. On the basis of that thought, the legislators also consider it necessary to formulate it in the Constitution. Article $28 \mathrm{H}$ of the 1945 Constitution of the State of the Republic of Indonesia (1945 Constitution of the Republic of 
- Volume 2 Issue 1, November 2017

Indonesia) clause (1) that: "Every person shall have the right to live physically and physically and physically, well and well, and have the right to receive health services".

Humans live in an ecosystem of the earth that consists of air space, land and sea. Pollution on land will affect the sea and air, hence the environmental problem can rise to become a global problem. Environmental problems at a larger level result in rising earth surface temperatures as a greenhouse effect (global warming).

Environmental issues need to be anticipated as early as possible to avoid getting to an alarming level. The problem of plastic waste clusters in the marine waters of Sorong City is currently a threat to the existence of the marine environment which can lead to various negative impacts. In plain view that this pollution can be disturbing from the aesthetic element, because to disturb the beauty of the sea. In addition to impacting the aesthetics, contamination of plastic waste in the sea can also affect the safety of fishermen as well as tourists who visit the Raja Ampat District that uses Speedboat.
The negative impacts of environmental pollution can affect health, namely the effects of polluted air, water and land either directly or indirectly. Direct effects such as the impact of air pollution on human respiratory and other living disorders can interfere with human respiration, whereas examples of indirect impacts eg humans inadvertently consuming fish that live in water containing heavy metals $(\mathrm{Hg})$ can result in disruption of human health such as disability born like the case of Minamata in Japan.

In the Elucidation of Article 2 of Law Number 32 Year 2009 on Environmental Protection and Management. the principles of state responsibility are:

a. The State ensures the utilization of natural resources will provide the greatest benefit for the welfare and quality of life of the people, both present and future generations.

b. The State guarantees citizens the right to good and healthy living;

c. The State prevents the use of natural resources that cause pollution and or environmental damage.

Water pollution in Indonesia also occurs in seawater, and the incident occurs throughout the waters of the 
archipelago. Increased sea pollution occurred after sea transportation since the 1980s became the mainstay of inter-island transportation in Indonesia (before that year in Indonesia only had KM Tampomas whose operating area did not cover Eastern Indonesia). When the motor boat cleaners (KM) PELNI clean organic waste and non-organic (plasitk) to the sea freely. The disposal of such garbage takes place independently, in which case there should be a standard operating operation (SOP) that must be obeyed by KM officers.

Actually the issue of sustainable development has been adopted by Law No. 4 of 1984 on UULH. This means that the utilization of natural resources in this case the sea should still pay attention to the ecological element. It means that the utilization of natural resources should pay attention to ecological, social, and economic aspects. In the general explanation of the Law gives understanding of the Indonesian Environment granted by God Almighty to the Nation and the People of Indonesia, is a grace from Him and must be developed and preserved ability in order to remain a source and life support for the Nation and the People of Indonesia and other creatures, for the sake of continuity and improvement of the quality of life itself.

The existence of this plastic waste has been predicted from the results of the National Oceanic and Athmosperic Admistration (NOAA) study from 1985 to 1988 stating the presence of high concentrations of plastic neutonics in the Alaska convergence zone, so the same conditions also occur in the North Pacific Ocean convergence zone. ${ }^{1}$

Similarly, the problem of marine pollution in the waters of Sorong City due to the handling of waste in the city area that is less effective has led to an increase in the amount of waste to disturb the sea surface. Increased marine pollution is not only measured by the amount of waste floating on the surface of the water, but most of the plastic waste will sink to the seabed so

\footnotetext{
${ }^{1}$ Day Robert H.; Shaw, David G.; Ignell, Steven E., Quantitative distribution and characteristics of neustonic plastic in the Nort Pacific Ocean. Final Report to US Departement of Commerce, National Marine Fisheries Service, Auke Bay Laboratory. Auke Bay, AK, 1988 , in Davilla Prawidya Azaria, Sucipto, SH., MH, Heru Prijanto, SH., MH (Jurnal ) "Perlindungan Lingkungan laut Samudra Pasifik Dari Gugusan Sampah Plastik Berdasarkan Hukum Lingkungan laut Internasional, Faculty of Law University of Brawijaya, p 3.
} 
it will disrupt the growth of coral reefs as a breeding ground for fish. The impacts of ineffective handling of waste (waste plastic) in the land area can have a wide impact on marine ecology especially if viewed from the aspect of sustainable development.

\section{METHOD OF THE RESEARCH}

The type of research is normativelegal research, which is used to study the rules of law or legal provisions with emphasis on the principles of law that relating to the international and national laws, especially related to the interaction between them.

The technique of data collection used is literature study, by studying various legal materials includes primary, secondary, and tertiary in accordance with the object of study. Data analysis is done by analyzing qualitative data by reducing data, presenting data and drawing conclusion.

\section{ANALYSIS AND DISCUSSION}

The name Sorong comes from the word Soren, in Biak Numfor language which means deep and bumpy sea. Soren said first used by the Biak Numfor tribe who sailed in ancient times with sailboats from one lupau to another island until arriving and settling in the Raja Ampat Islands. The boundaries of Sorong City are as follows:

a. West : Dampir Strait.

b. North : Makbon District and Dampir Strait.

c. East : Makbon District.

d. South : Aimas District and Salawati District.

Sorong City area is $656.64 \mathrm{~km} 2$ including one of the areas that the population is growing rapidly. The rapid growth of population in Sorong City can have implications on the various emergence of new problems. Environmental problems are generally related to the utilization of natural resources that can exceed the carrying capacity of the environment, resulting in environmental degradation. Environmental degradation or declining environmental carrying capacity may also be caused by errors in the utilization or use of natural resources. For example, population density in a region can cause environmental damage as a result of the inability of the environment to bear or bear a heavy burden. 
Table 1

Population Increase Period Year 2010 to Year 2016

\begin{tabular}{cccl}
\hline No & Year & Number of Population & \multicolumn{1}{c}{ Status } \\
\hline 1 & 2010 & 282.216 & $\begin{array}{l}\text { Increase the population of five thousand } \\
\text { six hundred seventy seven souls in a } \\
\text { year. }\end{array}$
\end{tabular}

\begin{tabular}{ccc}
\hline \multicolumn{3}{c}{ The population growth spurt between 2011 and 2015 amounted to Eighty six thousand one } \\
hundred and seven people.
\end{tabular}

The growth of population in Sorong City area is highly correlated with the increasing rate of pollution. Pollution on land will have an impact on increasing pollution rate in marine waters. This is because the pollutants, especially inorganic materials will naturally carry into the sea through the rivers.

Marine pollution caused by this event is called dumping. Article 60 of Law Number 32 Year 2009 on Environmental Protection and Management affirms that "every person is prohibited from dumping waste and/or material into environmental media without permission. Concerning dumping problems in the environment so far only leads to the prevention of B3 waste (Hazardous and Toxic Substances). However, as the rate of environmental pollution increases, it is necessary to extend the range in practice, that dumping in this case includes the disposal of inorganic waste into a medium.

Enforcement of Indonesian environmental law in the future needs to consider efforts to prevent the rate of environmental damage through legal awareness activities (kadarkum). That the definition of environmental pollution that is understood by the wider community so far is the activity of pollution on a large scale eg industrial waste. While small-scale pollution activities such as household waste disposal into the river has not been imposed sanctions.

The provisions of Article 1 point (14) which states that: "Environmental pollution is the entry or inclusion of living things, substances, energy, and / or other components into the 
environment by human activities so as to exceed the established environmental quality standards". Based on the above provisions that the activity of disposal of household waste to the river surface is a dumping activity that may be subject to sanctions.

The wealth of Indonesia's natural resources, especially the sea to date, has not been optimally exploited. Not optimal the utilization of natural resources, especially marine waters is caused by several things, namely the mastery of technology is still minimal and the following factors also are knowledge of the potential of marine resources are still simple. Simply knowledge of marine resources causes a lack of awareness of the importance of marine waters as a natural resource that stores various types of natural resources. The lack of knowledge on marine natural resources as one of the sources of Local Original Income (PAD) has a correlation with the increasing rate of sea water pollution.

Table 2.

Components Needs

\begin{tabular}{cccccc}
\hline Year & $\begin{array}{c}\text { Number of } \\
\text { Population }\end{array}$ & $\begin{array}{c}\text { Municipal } \\
\text { Waste } \\
\text { Generation } \\
(\mathbf{l t} / \text { person/day) }\end{array}$ & $\begin{array}{c}\text { Estimated } \\
\text { Total Waste } \\
\text { Generation } \\
\left(\mathbf{m}^{\mathbf{3}} / \mathbf{d a y}\right)\end{array}$ & $\begin{array}{c}\text { Trash } \\
\text { Transported } \\
\left(\mathbf{m}^{\mathbf{3}} / \mathbf{h r}\right)\end{array}$ & $\begin{array}{c}\text { Difference } \\
\left(\mathbf{m}^{\mathbf{3}} / \mathbf{d a y}\right)\end{array}$ \\
\hline 2003 & 174.145 & 3 & 522,44 & 115,12 & 407,32 \\
\hline
\end{tabular}

Source: www.sorongkota.go.id

In accordance with the standards of manage as much as $115.12 \mathrm{~m} 3 /$ day. So the city is, ie the level of waste generation of 3 liters/person/day. that the amount of unserved waste is Sorong City with a population of $407,32 \mathrm{~m} 3 /$ day. 174,145 people, yielding 522.44 (m3 / If referring to Table 2 above, then day). This amount is obtained from the population multiplied by 3/1000 (m3 / in 2014 the total population in Sorong City is 336,561 people, it can be day). But the new city of Sorong can described as follows: 
Table 3.

Components Needs

\begin{tabular}{cccccc}
\hline Year & $\begin{array}{c}\text { Number of } \\
\text { Population }\end{array}$ & $\begin{array}{c}\text { Municipal } \\
\text { Waste } \\
\text { Generation } \\
(\mathbf{l t} / \text { person/day })\end{array}$ & $\begin{array}{c}\text { Estimated } \\
\text { Total Waste } \\
\text { Generation } \\
\left(\mathbf{m}^{\mathbf{3}} / \mathbf{d a y}\right)\end{array}$ & $\begin{array}{c}\text { Trash } \\
\text { Transported } \\
\left(\mathbf{m}^{\mathbf{3}} / \mathbf{h r}\right)\end{array}$ & $\begin{array}{c}\text { Difference } \\
\left(\mathbf{m}^{\mathbf{3}} / \mathbf{d a y}\right)\end{array}$ \\
\hline 2016 & 382.101 & 3 & 1.009 .683 & - & - \\
\hline
\end{tabular}

Source: www.sorongkota.go.id

Indonesia's wider territory of the sea is actually one of the natural resources that has not been considered important as a source of State income. Regarding the territorial sea of Indonesia according to Djuanda Declaration, December 13, 1957 Indonesia declared to the world that the sea of Indonesia (sea around, between, and inside the archipelago of Indonesia into a unity of NKRI Territory.

Indonesia as an archipelago, has been recognized by the international community through the third UN Convention, United Nations Convention on the Law of the Sea 1982 (UNCLOS), then ratified by Indonesia with Law No. 17 of 1985, UNCLOS 1982, Indonesia to 5.9 million $\mathrm{km} 2$, consisting of 3.2 million $\mathrm{km} 2$ territorial waters and $2.7 \mathrm{~km} 2$ of Exclusive Economic Zone waters, this peraian area does not include continental shelf.
This makes Indonesia the world's largest archipelago in the world. ${ }^{2}$

The potential of Indonesia's large coastal and marine resources has not contributed significantly to the national economic development. The utilization is not yet optimal, even the natural resources degradation has occurred in some coastal waters due to the utilization that does not consider the carrying capacity of the environment ${ }^{3}$.

Pollution that occurs in coastal areas and oceans, derived from activities on land such as: Industry, household activities and agriculture, in addition there is also pollution derived from marine activity such as sea transportation activities ${ }^{4}$. Meanwhile, according to Churchill there are 4 main sources of marine pollution, namely: first, marine pollution activities conducted by shipping, second,

2 Ridwan Lasabuda, Tinjauan Toeritis Pembanguan Wilayah Pesisir dan lautan Dalam Perspektif Negara Kepulauan Republik Indonesia, Jurnal Ilmiah Platax, Vol.I-2, Januari 2013, ISSN:2302-589, p. 93.

${ }^{3}$ Ibid p. 96

${ }^{4}$ Ibid. 
dumping activities, the third seabed activities and the fourth activity on the ground and air (land based and atmospheric activities). Land and air activities are the largest source of marine pollution, accounting for about three-quarters of marine pollution is a pollution problem from land that enters the ocean ${ }^{5}$.

The cause of sea pollution of Sorong City is more likely caused by shipping and dumping activities. Shipping (shipping) for example caused by the voyage by the passenger ships are quite a lot of garbage. To avoid the accumulation of garbage in passenger ships is overcome by throwing waste into the sea surface, but this action is an action that is not justified by the principles of the environment.

Garbage discharged into the sea is in fact a lot of inorganic waste that decomposition takes hundreds of years, while the intensity of shipping activities is increasing so that the level of pollution caused by shipping (shipping) increased drastically.

\footnotetext{
5 .R. Churcill, A.V. Lowe, in Davilla Prawidya Azaria, dkk, Perlindungan Lingkungan laut Samudra Pasifik dari Gugusan Sapah Plastik Berdasarkan Hukum Lingkungan Internasional, in an Article
}

The increase in the volume of pollutants (pollutants) each year in line with the increase in population. Because the pollution that occurs is actually generated mostly by human activity.

In a developing country as agreed in the Stockholm Conference that the problems faced by the developing countries (the pollution of poverty) recognize the importance of attention addressed to environmental issues in developing countries, as stated in number 4:

In the developing countries, most of the environmental problems are caused by underdevelopment. Millions continue to live far below the minimum levels required for a decent human existence, deprived of adequate food and clothing, shelter and education, health and sanitation. Therefore, the developing countries must direct their efforts to development, bearing in mind their priorities and the need to safeguard and improve the environment. For the same purpose, the industrialized countries should make efforts to reduce the gap between themselves and the developing countries. In the industrialized countries, environmental issues are related to industrialization and technological development. ${ }^{6}$

6 Annual Review of United Nations Affairs 1971-1972, in Siti Sundari Rangkuti, Hukum Lingkungan Dan Kebijaksanaan Lingkungan Nasional, ed., Published in Unair 
Tackling the problem of increasing waste that is wasted into the sea causing pollution.

For people whose level of environmental awareness is adequate, the environmental problems are not as complicated as in countries where society has a low level of environmental awareness. One of the countries whose public awareness is quite high on the environment is the Netherlands. The Netherlands is among the most developed countries in terms of management, prevention of pollution and environmental destruction, as well as good and complete legislation systems. $^{7}$

\section{Land-based marine pollution}

The global human awareness of marine pollution began only in 1974 after the introduction of an international arrangement on the prevention of land-based marine pollution known as the Paris Convention of 1974, which was made in Paris on 4 June 1974. This convention originally applied to the

(AUP) campus C. Unair. Surabaya, 2005, p. 49.

Hamzah, Penegakan Hukum Lingkungan, Published by CV. Sapta Artha Jaya, Jakarta, 1997, p. 33.
European region, the Northeast Atlantic region and the Mediterranean Sea.

Marine pollution from the land will increase in line with the increasing number of population growth. Much of human activity or activity has the potential to generate waste, so that the 1974 Paris Convention on Land-based marine pollution could affect every policy of government in the administration. The administration of a government based on the provisions of legislation should contain environmentally enforceable rules, so that every member of the community may be bound by the rules even within a certain period of time the public may have an awareness to comply with the provisions of the legislation.

The role of local government in the environment

One of the considerations of the implementation of regional government according to Law Number 23 Year 2014 according to the Law of Regional Government in letter $b$ states that governance is directed to accelerate the realization of community welfare through the improvement of services, empowerment, and community participation, and the remoteness of 
regional competitiveness taking into account the principles of democracy, equity, justice, and uniqueness of a region in the system of the Unitary State of the Republic of Indonesia.

The realization of the welfare of the community is achieved through the improvement of services based on the authority possessed by the local government. In Article 27 paragraph (1) and (2) of Law Number 23 Year 2014 regarding Regional Government states that: (1) Provincial region is authorized to manage the marine natural resources in its territory. (2) "The provincial authority to manage natural resources at sea as referred to in paragraph (1) includes:

a. exploration, exploitation, conservation and management of marine resources outside of oil and gas;

b. administrative arrangements;

c. spatial arrangements;

d. participate in maintaining security at sea; and

e. participate in maintaining the sovereignty of the State.

With regard to the authority of the provinces in the management of marine resources, in the framework of efforts to protect marine resources or marine conservation activities in the marine waters of Sorong City for the occurrence of marine environmental damage into the waters of the province of West Papua. Considering the marine waters of Sorong City is currently very strategic to support the activities of Raja Ampat archipelago tourism then the local government must conservation activities to prevent the occurrence of marine environmental damage due to land-based marine pollution (land-based marine pollution). Pollutants that currently have damaged the marine environment of Sorong City is a cluster of waste made from plastic. This platic waste cluster can menggaggu marine traffic activity, especially small ships such as speed boats.

The problem of increasing plastic waste in marine waters of Sorong City can prove that the lack of waste handling in Sorong City. This problem is related to various things such as the high number of population growth is not followed by adequate facilities to anticipate the increasing amount of waste generated by per person every day.

The local government through the Regional Development Work Plan (RKPMD) needs to establish an accurate calculation of population growth with the number of facilities to 
be provided for waste management. The local government needs to increase the budget to provide facilities (garbage trucks, carts and officers) to adjust the increase of garbage volume in line with the population growth in Sorong City.

The regional regulation on waste management in Kota Sorong has been implemented with the enactment of Local Regulation No. 15 of 2013 on Solid Waste Management in Sorong City. Consideration in point $\mathrm{a}$, that population growth and changes in consumption patterns lead to increased volume, type, and characteristics of waste. Based on the above considerations (a) above indicates that the main environmental problem is caused by the increase of population and the consumption pattern of society.

Two factors causing the increase in the amount of waste as described above have actually been recorded through the residence service, while the problems of types and characteristics of waste can be known in number through the Department of Trade and Industry. The point is that in handling environmental problems need cooperation between various departments. Given the accurate data can be used as a consideration in the drafting of the budget.

Consideration of point $b$, the above-mentioned regional regulation states: "that waste management should be conducted comprehensively and integrated from upstream to downstream in accordance with environmental principles so as to not have a negative impact on public health and the environment; provide economic benefits, and can change people's behavior ". According to the General Elucidation of Law No. 18 of 2008 on Waste Management, what is meant by comprehensive waste management in this case is waste management is done from upstream. This means that before the result of a potentially waste product, up to downstream that is in the phase of the product has been used so that it becomes garbage, which is then returned to the environmentally safe media.

The high volume of garbage carried by the rain water from land to sea, especially plastic waste shows that comprehensive efforts, economic benefits, and can change the behavior of the community as being imposed in local regulations can't be implemented. Law as a tool of social engineering 
can't be done. In Article 5 paragraphs (1) and (2) of Regional Regulation No. 15 of 2013 on waste management in Sorong City, it stipulates that (1) Local Government shall prepare waste reduction and handling plans as outlined in the strategic plan and annual work plan. (2) The waste reduction and handling plan as referred to in paragraph (1) shall at least contain:

a. Target of waste reduction;

b. Target for the provision of facilities and infrastructure for waste reduction and handling from waste sources to TPA;

c. Patterns of regional cooperation development, partnership, and community participation;

d. The need for financing provided by local governments and communities; and

e. An environmentally friendly development plan and utilization of technology to meet the needs of reusing, recycling, and final waste handling.

The target of waste reduction that can be done nowadays especially plastic is by providing extension program to the community. There should be an explanation from the government that the plastic is very difficult to decompose by the bacteria decomposers so it can survive in a long time, so it is potentially disrupt the environmental sustainability. Thus the community was made aware that the use of plastic materials and plastic bags strived substitute media that is environmentally friendly materials.

The target of providing facilities and infrastructure of waste reduction and handling starting from waste source to TPA, needs to be procured by the government. Facilities and infrastructure provided by the government in the form of waste bins in public spaces need to be supervised eg green garbage trash is the type of organic trash, while the red color is a non-organic waste, while the blue color is a type of metal trash. Regarding the function of these colors are not widely understood by the public so the government needs to socialize.

In connection with this, the local government needs to be serious in enforcing the local regulations on waste in the city of Sorong. For example, to streamline the local regulation can be done by issuing the mayor's regulation as a regulation of its implementation if it is required. In principle, the establishment of legislation is also known as a principle that every legislation should be able to 
take into account the effectiveness of the legislation in society, both philosophically, juridically and sociologically.

As a correction to the implementation of waste management in Sorong City can also refer to the opinion of Soerjono Soekanto ${ }^{8}$, that law enforcement can be influenced by several things:

1. Legal factors;

2. Law enforcement factors (apparatus);

3. Facilities and infrastructure factors;

4. Community factors

5. Cultural factors.

Implementation of local regulations on waste in Sorong City needs to be tested whether from the aspect of legal aspect has been fulfilled from the point of principle so that its validity can fulfill the sense of justice in society. The point is that the effectiveness of a legislation is measured from the purpose of the establishment of legislation. If the objective of formulating such laws and regulations is not effective, it should be improved both in the legal aspects, law

8 Soerjono Soekanto, 2004,Faktor-faktor Yang Mempengaruhi Penegakan Hukum, Raja Grafindo Persada, Jakarta, p. 42 enforcers, infrastructure, community, and culture.

According Dellyana ${ }^{9}$, that law enforcement is an attempt to realize the ideas and concepts of law that people expect to become reality. Law enforcement involves many things. Therefore, the five factors mentioned by Soerjono Soekanto must play a role so that law enforcement of Local Regulation No. 15 of 2013 on Solid Waste Management in Sorong City can apply effectively.

Cultural factors is one factor that can also determine the enforcement of a legislation. In general, culture in Indonesia is not yet well established in terms of waste management. Almost in all corners of Indonesia, waste problems is a very serious problem in the administration. Therefore, in the formulation of the law on waste and all existing legislation under it contains the thought that the legislation on waste can change people's behavior. For example, in Article 7 of Local Regulation No. 15 of 2013 on Waste Management in Sorong City states as follows: "The local government in handling waste is done by:

9 Dellyana, Shant, 1988. Konsep Penegakan Hukum, Liberty.Yogyakarta, p. 32. 

a. Sorting;
b. Collection;
c. Transportation;
d. Processing;
e. Final waste processing.

Segregation of waste should be done since the household, it is important to apply in order to facilitate the handling of garbage by the garbage collector. Garbage producers are required to sort out garbage can also instill that there is responsibility to every garbage producer to participate in handling waste. Garbage originating from households is also required to be sorted according to the type of garbage, so it is expected that in the future there will be a good habit in handling waste.

In relation to community participation in handling waste, the local government of Sorong City can seek to develop public awareness in waste management. Efforts to cultivate public awareness can be done by setting rules that are obligatory to be adhered to by the community regarding waste disposal procedures that meet the standards, procedures and criteria.

Handling of waste that meets the standards, procedures, and criteria mentioned above will be possible if done in a comprehensive and integrated manner. The point is that the handling of waste should involve all the parties concerned, both businesses that generate industrial waste, although in the criteria that this waste is included type of household waste.

Sorong City Government should be able to guarantee the implementation of a good and environmentally sound waste management that aims to improve public health. Handling of environmentally sound waste can be done by the local government of Sorong City by planning waste reduction in the work plan by the local unit of work unit in charge of garbage problem.

Strategy of local government as a preventive measure of increasing the waste that empties into the sea waters of Sorong City can be done by improving the service of handling household waste. Household wastes, especially materials made of plastic materials that are not transported to landfill (TPA) will be carried by the rain water to the sea. Therefore, local governments must improve the service of facilities and infrastructure of landfills from households, public places, small and medium industrial 
areas so that all the waste can be handled by garbage collectors.

It should be remembered that in the case of pollution and environmental damage has occurred, the steps to be taken is a repressive effort in the form of effective, consistent and consistent law enforcement against pollution and environmental damage that has occurred. Therefore, the local government of Sorong City must develop a system of handling waste or waste, especially waste plastic type carried by river water flow into the sea. Given the plastic waste can disturb species of marine life including coral reefs as a breeding ground for fish in the sea.

Efforts to improve supervision of industries, especially industries that have the potential to produce waste plastic, local government should continuously provide supervision. Article 90 Paragraph (1) of the Law on Environment affirms that "government agencies and local governments responsible for the environment shall have the authority to file claims for compensation and certain actions against businesses and/or activities that cause pollution and/or environmental damage resulting in environmental losses. The effort is one form of local government responsibility if it is clear that a business has found an act of environmental pollution.

The authority of the Regency/Municipal Government in Article 63 paragraph (3) of the UUPPLH or Environment Act shall include:

a. establishing district-level policy;

b. stipulate and implement SEA at the Regency / City level;

c. establish and implement policies on RPPLH at the district / city level;

d. establish and implement policies on AMDAL and UKLUPL;

e. organize an inventory of natural resources and greenhouse gas emissions at the district / city level;

f. develop and implement cooperation and partnership;

g. develop and apply environmental instruments;

h. facilitate dispute settlement;

i. conducting guidance and supervision of obedience of responsible business and / or activity to the provision of environmental permit and legislation in the field of environmental protection and management;

j. implementing minimum service standards;

$\mathrm{k}$. implementing policies on the procedure of recognizing the existence of indigenous and tribal peoples, local wisdom and the rights of indigenous 
and tribal peoples concerned with the protection and management of the environment at the district/city level;

1. managing environmental information at district/city level;

m. develop and implement environmental information system policies at the district/city level;

n. provide education, training, coaching and awards;

o. issuing environmental permits at the district/city level; and

p. enforcing environmental law at the district/city level.

\section{CONCLUSION}

Increasing the amount of waste plastic in the waters of Sorong City can disrupt the convenience of sea users, especially fishermen and tourists who aim to the Raja Ampat Islands and can also impact on the increasing ecological damage of the sea.

The handling of increasing the amount of plastic waste in Sorong City should be carried out by aligning the population with the facilities and waste cleaning officers in urban areas as well as socializing the use of garbage provided by the local government with color variations to facilitate the handling of garbage for the community and officers.

\section{BIBLIOGRAPHY}

Day Robert H.; Shaw, David G.; Ignell,

Steven E., Quantitative distribution and characteristics of neustonic plastic in the Nort Pacific Ocean. Final Report to US Departement of Commerce, National Marine Fisheries Service, Auke Bay Laboratory. Auke Bay, AK, 1988 , in Davilla Prawidya Azaria, Sucipto, SH., MH, Heru Prijanto, SH., MH (Jurnal)“ Perlindungan Lingkungan laut Samudra Pasifik Dari Gugusan Sampah Plastik Berdasarkan Hukum Lingkungan laut Internasional, Faculty of Law University of Brawijaya.

Dellyana, Shant, 1988. Konsep Penegakan

Hukum,

Liberty.Yogyakarta,

Hamzah, 1997. Penegakan Hukum

Lingkungan, Published by CV.

Sapta Artha Jaya, Jakarta.

Ridwan Lasabuda, Tinjauan Toeritis Pembanguan Wilayah Pesisir dan lautan Dalam Perspektif Negara Kepulauan Republik Indonesia, Jurnal Ilmiah Platax, Vol.I-2, Januari 2013, ISSN:2302-589. 
Papua Law Journal @ Volume 2 Issue 1, November 2017

R. Churcill, A.V. Lowe, in Davilla Prawidya Azaria, dkk, Perlindungan Lingkungan laut Samudra Pasifik dari Gugusan Sapah Plastik Berdasarkan Hukum Lingkungan Internasional, in an Article.

Soerjono Soekanto, 2004, Faktorfaktor Yang Mempengaruhi Penegakan Hukum, Raja Grafindo Persada, Jakarta.
Articles:

Annual Review of United Nations Affairs 1971-1972, in Siti Sundari Rangkuti, 2005. Hukum Lingkungan Dan Kebijaksanaan Lingkungan Nasional, ed., Published in Unair (AUP) campus C. Unair. Surabaya.

\section{Website:}

www.sorongkota.go.id 